British Columbia. That is, we continue to add 10000 to 14000 ha per year to the backlog NSR total. These areas are mostly made up of brushed-in areas, difficult planting ground, poor survival sites - the toughest rehabilitation challenges imaginable.

A key task now is to arouse sufficient public, bureaucratic and political interest before the state of our forest mismanagement becomes desperate. At that late stage the deterioration may become irreversible in practical terms to deal with, or too costly for the governmental and industrial players to handle.

As an aside, we have corporate presidents who are responsible for the management of huge tracts of Crown Lands who don't understand how bad things are. One recently said, "I do not think the industry will suffer because of a short-term let-up in (the government's expanded reforestation) funding efforts." Another company president said, "The present plan to treat approximately 110000 ha (10\%) of backlog NSR and problem stands over the next five years is inadequate, but recognizes the financial realities of the times."

I said it would take arousal of public, bureaucratic and political interests to get some action. We all know why we need public support - the people own most of the forests we manage and their spending priorities govern the resources we get to do our job. As long as we have a huge backlog of NSR, we shall never have credibility; and all the policy initiatives and refinements in the world won't convince the public that fores- ters are doing their jobs. As F.L.C. Reed often says, "The finest forest management policies won't buy you a cup of coffee if you don't put them into practice with adequately funded programs."

Thank you very much for your attention. I'm glad to see this interest in forest policy, especially when there are so many interesting papers being presented at the other Working Group meetings, In that vein, here's one last Murphy's law: "At a conference like this, the most interesting paper will always be scheduled simultaneously with the second most interesting paper." There just have to be a lot of people at the other Working Group meetings wishing they were here right now.

\section{References}

British Columbia Ministry of Forests. 1979. Provincial forests. A discussion paper prepared by Planning Division. $46 \mathrm{p}$.

1980, 1981, 1982, 1983. Five-Year Forest and Range Resource Program

1980-83. Ministry Policy Manual.

1980. Forest and Range Resource Analysis Technical Report, $802 \mathrm{p}$

1981. Public Involvement Handbook

Block, A. 1982. Murphy's Law - book three. Price/Stern/Sloan, Los Angeles. $93 p$

Pearse, P.H. 1976. Timber rights and forest policy. Report of the Royal Commission on Forest Resources, Victoria, $395 p$

\title{
The Evolution of Crown Land Forest Policy in Ontario ${ }^{1}$
}

\author{
by
}

\author{
W.K. Fullerton'2, RPF
}

The difficulty in developing forest policy is related to the perversity of Nature. That is, you cannot successfully determine beforehand which side of the bread to butter. To the people responsible for preparing policy options for the consideration of governments, there is better than a 50:50 chance the bread will fall butter-side down.

The purpose of this paper is to show that good choices have been made in Ontario, and that the evolution of forest policy has been well coordinated and developed in the best possible direction. The progress in forest management has been constant, consistent, and credible in Ontario.

It would be interesting to trace the evolution of forest policy in Ontario from 1867 to the present. Certainly there would be many instances of history repeating itself. Indeed the words of learned political leaders of the early days are often quoted to show that the more things change, the more they are the same. However, this paper will deal briefly with an overview of major policy changes, basically since World War II, as a background to current policy thrusts and directions. It will deal only with the policy affecting Crown lands. The evolution of forest policy for private lands is another fascinating study

\footnotetext{
A talk prepared for the Forest Policy Working Group. Canadian Institute of Forestry, Sault Ste. Marie, Ontario, Oct. 6/83

2Director, Forest Resources Branch, Ontario Ministry of Natural Resources.
}

that should await the outcome of current initiatives. Further, it should be understood that the words and ideas presented here are not original, and have largely been written by others.

\section{An Historical Perspective}

Before the second world war, Ontario was lurching towards a policy of sustained yield management. In the 1920 s, the province sought the exploitation of the abundant and largely overmature spruce forest for the manufacture of pulp following the decline of the white pine trade. At the same time, legislation was passed - the Forestry Act of 1927, the Provincial Forests Act, and the Pulpwood Conservation Act of 1929 - that provided respectively for the separation of farm and forest lands, the setting aside of timber reserves for future use, and the requirement that pulp companies manage the Crown forests on a sustained yield basis. In 1930, a monumental work entitled The Forest Resources of Ontario, by Sharpe and Brodie, was the first comprehensive inventory of Ontario's forests and set the stage for the move to sustained yield management. However, the great depression of the 1930 s did not provide a climate conducive to economic development so that the Pulpwood Conservation Act was destined to be ineffective.

The second world war not only lifted the world economy out of the depression, but develoiped the technology for accurate 
aerial inventory of the forest. A complete inventory accompanied by sustained yield forest management plans was completed between 1948 and 1958. The management plans brought to light the severe imbalance of age classes of the natural forest, and the need to accelerate the harvest in virtually every management unit, and therefore promote the utilization of the resource and encourage investment in new manufacturing plants.

The Kennedy Royal Commission on Forestry (1947) made many recommendations concerning improved timber utilization. The Commission recognized the need for forest management and emphasized that: "Unless the public is willing to spend large sums of money on forestry in the next 25 years, efforts toward imporvement or even maintenance of the present forest conditions will continue to be little better than a gesture."

Thus, after a century in which the natural forest had been exploited to provide capital, employment and agricultural land to a developing provincial economy, it was perceived that investment would be necessary to ensure forests for the future.

Between 1947 and 1962, new legislation, such as the Forest Management Act (1947), the development of the Ontario Department of Lands and Forests - particularly in the undertaking of the forest resources inventory (FRI), together with the setting up of Crown Forest Management Units, provided a major impetus to certain aspects of forestry. The number of professional foresters and technicians employed by government and industry increased dramatically. Seven new tree nurseries to provide planting stock for reforestation were established in northern Ontario, in addition to the four in southern Ontario.

A new Crown Timber Act was enacted in 1953. Although the act reiterated that the licensee was responsible for undertaking both harvesting and regeneration of Crown timber with few exceptions little integration of these two activities was accomplished.

Although failure to commence such forest management generally can be attributed to both inaction by industry and lack of impetus by the Crown, it is important to realize that the necessary professional and technical expertise and knowledge to provide for such management was just being developed - largely by government foresters in the Crown Forest Management Units. The view of industry was that natural regeneration would follow harvesting, and that technological development would permit industry to utilize the future forest.

Two other factors contributed to the slow development. First, much of the northern forest lands was being inventoried for the first time and much of it was inaccessible. Without either inventory or access, forest management was not possible. Second, in the 1950s, the initial reforestation in northern Ontario relied on experience and often on planting stock that had been developed in the reforestation of sandy lands in southern Ontario. The result was often failure, and it was some time before effective regeneration techniques were developed for the cutover boreal forest lands of northern Ontario.

The sustained yield model for forest management requires regeneration after harvesting. With an underutilized and overmature natural forest, rotation ages can be lengthy to allow for an extended regeneration period. However, even before the province-wide inventory was complete, Project Regeneration was launched. This was a crash technology development program undertaken by field staff. It was recognized that rapid regeneration would be desirable in the future and the province had better learn how to do it. After 1956 silvicultural technology specifically for northern Ontario devel- oped rapidly in the fields of seed collection, nursery practice, site preparation, planting, tending, and protection. In 1966, Ontario began the first major production of container seedlings, a development that was immediately picked up and refined by foresters in Scandinavia and British Columbia. By 1960 , it was clear that the forest industry was not doing an effective job of regeneration. Accordingly in 1962, the Crown Timber Act was amended and the province assumed full responsibility for regeneration.

The Brodie Study Unit Report of 1967, undertaken for the Department of Lands and Forests, stressed the need for not only developing silvicultural expertise, but having it within a management framework to ensure continued forest production.

In 1972, the Forest Production Policy was approved in principle by the Government of Ontario. It spelled out the range of options for long-term forest production and the costs of achieving such options. The detailing of such a policy was unique in Canada and undoubtedly this policy, together with the wealth of silvicultural expertise developed over the preceding two decades, provided a firm base on which to develop forest management agreements.

The result of government assuming responsibility for regeneration, while the companies concentrated on harvesting, was that increasingly what was efficient and effective for one - the harvesting - created problems and inefficiency for the other - regeneration. Forestry involves both harvesting and regeneration; indeed, often harvesting is, or should be, the first step in the regeneration process.

The problems and inefficiencies resulting from separating responsibility for these two actions were recognized by both the Ontario government's special program review of 1975 and the Armson Report Forest Management in Ontario/ 1976. Both recommended that the licensee integrate the planning and assume the responsibility for harvesting and regeneration.

\section{Forest Management Agreements (FMA)}

In 1977, a brief from the Ontario Forest Industries Association to the Minister of Natural Resources indicated agreement in principle to transferring responsibility for forest management from government to industry.

Simply the proposal recommended:

i) a defined basis of tenure:

ii) provision of suitable incentives to encourage the licencee to undertake management; and

iii) an effective process to monitor and review achievement in management.

During 1978 and 1979 , negotiations between the Ministry of Natural Resources (MNR) and pulp and paper companies resulted in the development of forest management agreements, which came into being with the Crown Timber Amendment Act of 1979. The first agreement was signed with Abitibi-Price for the Iroquois Falls Forest in April of 1980. As of March 31, 1984, 22 agreements have been signed, covering some $114900 \mathrm{~km}^{2}$ or $47 \%$ of the licenses Crown forest area of the province.

Forest management agreements are contractual arrangements between the Crown and certain forest companies, whereby a company undertakes the forest management practices of planning, road construction, harvesting, regeneration, and forest tending on behalf of the Ministry of Natural Resources

The agreements are essentially the same for all companies, differing only in the particulars relating to specific forest conditions and practices for an area. The purpose of a 
forest management agreement is:

To provide for a continuous supply of forest products to the agreement holder and to ensure the forests are harvested and regenerated on a sustained yield basis. The terms of the agreement are comprehensive. Some of the key provisions are:

- Tenure: The agreement is for 20 years, but at fiveyear intervals performance and obligations are reviewed and revised. If judged satisfactory, the agreement is extended a further five years. This is termed an "ever-green" agreement.

- Planning and documentation: The company must prepare forest management plans (20-year period), operating plans (five-year period), annual plans, and annual reports.

- The annual allowable cut (AAC): This is calculated in relation to actual depletions of the forest from cutting, fire, insects and disease; and additions resulting from regeneration and growth of the forest. The AAC is to be recalculated every five years at the time of the Ministry's review of company performance.

- Withdrawals of forest land: Land representing up to $5 \%$ the AAC may be withdrawn by the Minister for other purposes in the public interest. However, land withdrawn in excess of $5 \%$ must be replaced with comparable forest lands. The company shall also be compensated for buildings, structures and other items that may exist on the withdrawn lands.

- The costs of roads and regeneration: MNR takes the responsibility for certain basic funding on Crown lands under agreement. Roads are essential for effective management and use of the forest. The Ministry will therefore fund to a prescribed level the construction, reconstruction and maintenance of specified roads. For regeneration, MNR will pay its own costs for site preparation, planting or seeding, and tending where necessary. MNR will also provide free-of-charge all necessary tree seed and nursery planting stock.

- Prescriptions for forest management practices and standards: They are developed cooperatively by MNR and company staff prior to an agreement, and are contained in the Ground Rules - a schedule of the forest management agreement. Performance standards are included with the prescriptions.

- Incentives to increase forest productivity: Where a company undertakes silvicultural treatments solely at its own expense, the increase in volume attributable to those treatments shall be available at onetenth of the normal stumpage charges.

- Public participation, access and use: The company is required to conduct public meetings during the preparation of management and operating plans. Of particular importance are road corridors and sensitive areas. General public access and recreational uses, that previously existed in licenced Crown forest land, are continued on agreement area.

Two other recent policy initiatives should be mentioned - namely, land use guidelines and a class environmental assessment for forest management.

\section{Land Use Planning}

The Ministry of Natural Resources Land-Use Planning Guidelines represent an important attempt to improve land use decision making throughout the province. It is an effort by government - after extensive study and public consultation - to provide a comprehensive inventory of a multitude of natural resources and to identify future opportunities for developing Ontario's resource wealth.

The need for a more comprehensive approach to land use became evident in the early 1970s. During this period, both traditional resource industry activities and demand for high quality outdoor recreational opportunities increased. As competition for resources intensified, Ontario recognized the need for an integrated approach to resource management that would replace the traditional first-come, first-served approach to allocating resources. What was needed was a carefully considered strategy that would be flexible enough to accommodate changing needs, attitudes and knowledge of resource potential, and the technical ability to develop it.

The guidelines are also an attempt to integrate various land use programs undertaken by the Ministry over the years and to develop broad proposals for resource sharing.

The goal of the Ministry's land use planning program is to ensure that the people of Ontario receive the greatest continuous benefits from their natural resources.

The objectives of district land use planning are:

i) to provide a comprehensive inventory of Ontario's resources and their potential for development;

ii) to identify and maintain opportunities for economic and social development;

iii) to provide a means of testing the feasibility of achieving desired resource management targets and to reconcile those targets when the conflict;

iv) to provide a forum for public comment on the Ministry's land use proposals and to facilitate public involvement in the process of resource development; and

v) to provide guidelines for integrated resource management that will help achieve policy objectives and minimize related difficulties.

In developing the land use guidelines, MNR has carefully considered that there are multiple, sometimes competing, resource demands on any particular land base. It has attempted to accommodate as many of these demands as possible. To make efficient use of the land and water base, tradeoffs are necessary to resolve conflicts and maintain flexibility. Above all, it is necessary to encourage user groups to adopt a more positive attitude toward resource sharing.

In reviewing draft proposals for norther Ontario, the forest products industry expressed concern that insufficient softwood timber would be be available to meet future needs, and that areas withdrawn from logging may be excessive.

Recreational users of Crown land and the tourism industry argued that the forest industry was being given undue priority, and that the importance of other contributors to the economy, including tourism and recreation, was not being heeded. Environmentalisits and park advocates argued that expansion of the parks system was being constrained because of previous forest management commitments.

Recognizing the importance of the forest industry and the dependence of many communities upon it, MNR undertook a company-by-company analysis of wood supply requirements to the year 2000 . This had led the Ministry to conclude that although supplies will be tight for the forest industry by the turn of the century, the situation is manageable through appropriate strategies.

New MNR policies on resource access and modified management areas should increase the net availability of timber. Since the economic well-being of the forest industry depends on the old or natural forest, careful management is required. The FMA policy of accelerated access allows for cutting the oldest trees first to mitigate fire, insect and disease losses. Improved utilization standards are under discussion with industry to reduce waste in logging. Research and development are being fostered by Ontario to encourage use of 
underutilized species and a low quality raw material. The importance of private land to achieving timber targets is being addressed in a current MNR study on private land forestry.

The Ministry has developed a flexible eight-point provincial policy on access roads. This policy ensures that access roads will be built in support of the province's resource development and use objectives, but ensures a full site-bysite assessment of the need for access routes, specific locations and full public consultation. This is intended to balance the concerns of resource extraction companies over access to raw materials with the interests of tourist operators in maintaining the remoteness of their locations and protecting fish and wildife populations. Roads may be closed when deemed appropriate

Draft land use plans for northern Ontario defined forest reserves as areas requiring special forms of management to provide protection for adjacent waterbodies; to maintain forest productivity; to protect fish and wildlife habitat; to preserve special historical, geological or botanical features; and to ensure an esthetically pleasing environment along wilderness travel corridors.

The forest products industry responded by stating that few reserves should exist and those that do should be small and permit harvesting. Tourist operators and users of Crown land called for an extensive system of forest reserves. To balance these concerns, the MNR has developed a modified management area policy aimed at providing a suitable system of sharing resources in these areas.

Terms like "forest reserve", "lake reserve", and "buffer" have been replaced by the term "modified management area". The policy is intended to achieve integrated resource management for all areas of this kind. It is flexible and aimed at protecting specific resource values.

Development of the land use guidelines required the careful balancing of a number of economic, social, and environmental objectives. It provides a comprehensive inventory of the natural resource potential, a realistic framework for private sector investment, and an important source of direction for integrated resource management.

\section{Environmental Assessment}

The Class Environmental Assessment for Forest Management has been developed over the last seven years. The document forms the basis of the Ministry's approach to compliance with the Environmental Assessment Act for the program of forest management on Crown Lands. The document has been submitted by MNR and is undergoing selected public scrutiny before being accepted by the Minister of Environment. Because it is 140 pages long and has 50 pages of appendices, it will only be highlighted here

Forest management for the purposes of environmental assessment is defined as "sustained yield timber production", which is the integrated, interrelated, sequential series of activities undertaken to access and harvest an existing harvestable forest resource, and to replenish that resource in order to ensure continued production of a forest crop to supply the forest industry in perpetuity.

The document requires two major changes:

i) public consultation in the management planning process; and

ii) accommodation of other resource uses, that is integrated resource management.

It also requires the revising of management planning manuals and updating the silvicultural guidelines, manuals and procedural directives. It further provides for the elevation of a particular management plan or part thereof to be "bumped up" from a class level to an individual or specific environmental assessment level. The environmental assessment process would be phased in over a period designed to coincide with the 20-year management plan and the five-year or ten-year operating plan renewal date. What the environmental assessment process and land use guidelines show are the partnership nature of public policy dealing with resource planning in Ontario.

\section{Evolving Strategies}

These, then are the highlights of the evolution of forest policy in Ontario with particular emphasis on the last five years and principal issues; but this is not the end of the story. The evolutionary process continues in the pursuit of the following two-fold objectives:

- Resource development (i.e. to stimulate the development of Ontario's natural resources), and

- Resource conservation (i.e. to ensure the wise use of Ontario's natural resources)

It is apparent that with finite inputs of natural resources, manpower, money and time, policy must pursue integrated management strategies involving multiple use and sequential use The long-term policy thrusts that must be continued are:

i) to improve planning elements, such as the forest production policy:

ii) to achieve a much greater involvement of those outside MNR in the management of the forest resource:

iii) to achieve a much greater involvement of those outside MNR in the financing of resource management activities

iv) to achieve a greater level of social, economic and environmental benefits from the "old forest" trhough better access, protection and utilization

v) improve substantially the growth, yield, and flow of net benefits from the "new forests" through more efficient utilization of existing manpower and money; this involves selectivity in intensive versus extensive management, low cost regeneration techniques, age-class adjustment, expanded technology development and transfer, and sequential land use.

\section{Conclusion}

This overview presents the progression of forest policy development and its future direction. Focus has been placed on three principal areas: forest management agreements, land use guidelines and environmental assessment. These areas should be seen as the logical, progressive steps in bringing forest policy and forest management into the $1990 \mathrm{~s}$

There is much to be done to stretch the old forest, to balance age classes, and to establish and protect the new forest. The main point to be made, however, is that forest policy is not just forest renewal, nor it is just regulation. It is a multifaceted mandate that is based on social and economic goals. In Ontario, at least since the second world war, the progress that has been made in forest policy has been continuous, consistent, creative and credible. 